\title{
Solid phase microextraction as a reliable alternative to conventional extraction techniques to evaluate the pattern of hydrolytically released components in Vitis vinifera L. grapes
}

\author{
Rosa Perestrelo ${ }^{\mathrm{a}, \mathrm{b}}$, Michael Caldeira ${ }^{\mathrm{a}, \mathrm{b}}$, José S. Câmara ${ }^{\mathrm{a}, *}$

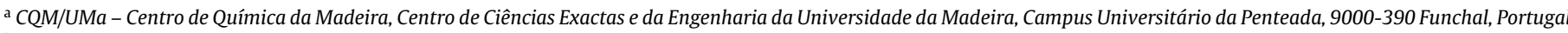 \\ b QOPNA, Departamento de Química, Universidade de Aveiro, 3810-193 Aveiro, Portugal
}

\section{A R T I C L E I N F O}

\section{Article history:}

Received 16 November 2011

Received in revised form 28 February 2012

Accepted 5 March 2012

Available online 10 March 2012

\section{Keywords:}

Vitis vinifera $\mathrm{L}$.

Hydrolyzed components

Liquid-liquid extraction

Solid-phase microextraction

GC-qMS

\begin{abstract}
A B S T R A C T
In present research, headspace solid-phase microextraction (HS-SPME) followed by gas chromatography-mass spectrometry (GC-qMS), was evaluated as a reliable and improved alternative to the commonly used liquid-liquid extraction (LLE) technique for the establishment of the pattern of hydrolytically released components of 7 Vitis vinifera L. grape varieties, commonly used to produce the world-famous Madeira wine. Since there is no data available on their glycosidic fractions, at a first step, two hydrolyse procedures, acid and enzymatic, were carried out using Boal grapes as matrix. Several parameters susceptible of influencing the hydrolytic process were studied. The best results, expressed as GC peak area, number of identified components and reproducibility, were obtained using Prozym M with b-glucosidase activity at $35^{\circ} \mathrm{C}$ for $42 \mathrm{~h}$. For the extraction of hydrolytically released components, HS-SPME technique was evaluated as a reliable and improved alternative to the conventional extraction technique, LLE (ethyl acetate). HS-SPME using DVB/CAR/PDMS as coating fiber displayed an extraction capacity two fold higher than LLE (ethyl acetate).

The hydrolyzed fraction was mainly characterized by the occurrence of aliphatic and aromatic alcohols, followed by acids, esters, carbonyl compounds, terpenoids, and volatile phenols. Concerning to terpenoids its contribution to the total hydrolyzed fraction is highest for Malvasia Cândida (23\%) and Malvasia Roxa (13\%), and their presence according previous studies, even at low concentration, is important from a sensorial point of view (can impart floral notes to the wines), due to their low odor threshold ( $\mu \mathrm{g} / \mathrm{L}$ ). According to the obtained data by principal component analysis (PCA), the sensorial properties of Madeira wines produced by Malvasia Cândida and Malvasia Roxa could be improved by hydrolysis procedure, since their hydrolyzed fraction is mainly characterized by terpenoids (e.g. linalool, geraniol) which are responsible for floral notes. Bual and Sercial grapes are characterized by aromatic alcohols (e.g. benzyl alcohol, 2-phenylethyl alcohol), so an improvement in sensorial characteristics (citrus, sweet and floral odors) of the corresponding wines, as result of hydrolytic process, is expected.
\end{abstract}

C 2012 Published by Elsevier B.V.

\section{Introduction}

Vitis vinifera L. grapes are composed by different groups, as non-volatile precursors, including unsaturated lipids, phenolic acids, S-cysteine conjugates, glycoconjugates, among others. These non-volatile glycosidically linked odorless components (aglycones) are susceptible to transformation into hydrolytically released volatile compounds during the winemaking process $[1,2]$. The hydrolytically released components could be terpenoids (e.g. linalool, geraniol, linalool oxide), $C_{13}$ norisoprenoids (e.g. (E)- $\beta$-damascenone), linear ( $C_{6}$ alcohols) or aromatic alcohols (e.g. 2-phenylethyl alcohol, benzyl alcohol), volatile phenols (e.g.

\footnotetext{
* Corresponding author. Tel.: +351 291705112; fax: +351 291705149

E-mail address: jsc@uma.pt (J.S. Câmara).
}

eugenol, 4-ethylphenol), among others [3,4]. These hydrolytically released components are linked to different derivatives, grouped in four sub-groups according to the sugar moieties, $6-0-(\alpha$-L-arabinofuranosyl)- $\beta$-D-glucopyranose, $6-0-(\beta-D-$ apiofuranosyl)- $\beta$-D-glucopyranose, $6-O$-( $\alpha$-L-rhamnopyranosyl)$\beta$-D-glucopyranose, and $\beta$-D-glucopyranose (Fig. 1) [3,5-8]. Moreover, these glycosides are not present in all varieties, and their content also differ according to grape varieties [9]. The glycosidically linked components can be released during winemaking due to the mild acid conditions of grape juice and wines, or through the action of endogenous or exogenous enzymes with b-glucosidase activity [3,10-12]. Acid hydrolysis occurs very slowly during wine storage and therefore simulates the reactions which take place during wine aging. Nevertheless, this hydrolyze pathway can promote molecular rearrangements, particularly in monoterpenols $[3,13]$. Enzymatic hydrolysis is carried out with various enzymes 


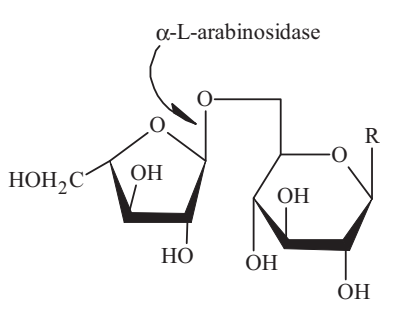

6-O- $\alpha$-L-arabinofuranosyl- $\beta$-glucopyranose

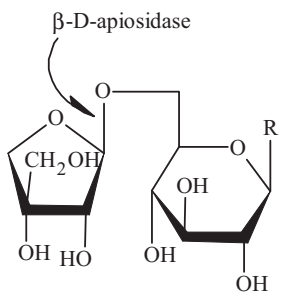

6-O- $\beta$-L-apiofuranosyl- $\beta$-glucopyranose

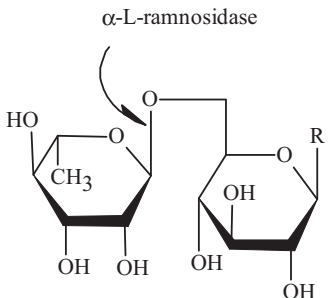

6-O- $\alpha$-L-rhamnopyranosyl- $\beta$-glucopyranose
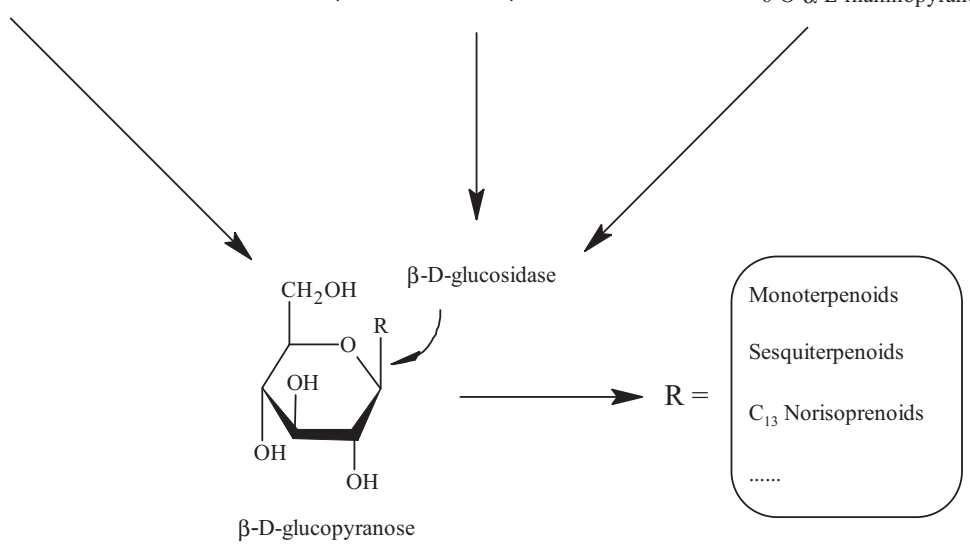

Fig. 1. General glycoconjugate structures and hydrolytically released chemical groups occurring in Vitis vinifera L. grapes.

which act sequentially according to two steps (Fig. 1): firstly $\alpha$ L-arabinosidase, $\beta$-D-apiosidase and $\alpha$-L-rhamnosidase make the cleavage of the terminal sugar, and arabinose, apiose or rhamnose and the corresponding $\beta$-D-glucosides are released; subsequently liberation of hydrolytically released components takes place after $\beta$-D-glucosidase action.

The most suitable enzymatic preparations to be used during winemaking process are those which have all $\beta$-D-glucopyranosidase, $\quad \alpha$-L-arabinofuranosidase, $\quad \alpha$-Lrhamnopyranosidase, and $\beta$-D-apiofuranosidase activities. This hydrolysis pathway showed a higher releasing potential compared to acid hydrolysis, consequently is considered for some authors as more suitable to measure the aroma potential of grapes $[3,6,14,15]$. The hydrolytically released components are generally present in trace amounts, therefore a previous extraction and concentration step of is required. Several techniques have been proposed to extract glycosidically linked components from grape [3,6-8,10,11,16-21], wines [3,17,20,22-24], and fruits [25-27]. Most of these studies applied conventional techniques based on solid-phase extraction (SPE), either in Amberlite XAD-2 polymeric sorbents $[6,7,11,16,18,21,25-27]$ or in $C_{18}$ reversed-phase sorbent $[3,6,8,10,17,20,23,24]$, microwaves [19], liquid-liquid extraction (LLE) [6-8,11,18,23,25-27], among others. Nevertheless, these techniques require organic solvents, and present some drawbacks, such as the possibility of sample contamination, and loss of analytes during the concentration step. Additionally, they are time-consuming and in general require high temperatures and large sample amount. Recently, stir bar sorption extraction (SBSE) [5], and solid-phase microextraction (SPME) [24] appears as a powerful means to analyze the hydrolytically released components after acid hydrolysis from grape and wines, respectively. Moreover, SPME is fast, easy to use, solvent-free, sensitive, preventing artifacts formation, and can integrates sampling, extraction, and concentration into a single step [28].

A previous study has applied headspace solid-phase microextraction (HS-SPME) combined with gas chromatography-quadrupole mass spectrometry (GC-qMS) to analyze terpenoids released after acid hydrolysis in wines [24]. In the current research, an alternative approach based on HS-SPME/GC-qMS methodology was tested to establish the pattern of hydrolytically released components of $7 \mathrm{~V}$. vinifera L. grape, commonly used to produce the world-famous Madeira wine. A comparison with the most commonly used methodology, LLE (ethyl acetate), was performed. Hydrolytically released grape-derived volatiles are indicated as possible aglycones to key aroma compounds of wines produced from non-aromatic grapes such as those considered in this research, Malvasia Cândida, Malvasia Roxa, Bual, Sercial, Terrantez, Verdelho and Tinta Negra. This information is very useful as an index for winemakers to determine, for instance, the optimal maturity of grapes, and optimize some winemaking steps (e.g. maceration time, enzyme addition), to obtain higher quality wines or even bring about new forms of carrying out the winemaking process. Moreover, no systematic study has been carried out so far to characterize the glycosidically linked fraction of these varieties.

\section{Experimental}

\subsection{Reagents and materials}

All chemicals were of analytical quality. Anhydrous sodium sulfate (99.0\%), ethanol (99.5\%), sodium chloride ( $\mathrm{NaCl}, 99.5 \%)$, and sodium hydrogen phosphate $\left(\mathrm{Na}_{2} \mathrm{HPO}_{4}, 99.0 \%\right)$ were purchased from Panreac (Spain, Barcelona). Citric acid $\left(\mathrm{C}_{6} \mathrm{H}_{8} \mathrm{O}_{7}, \geq 99.5 \%\right)$, LiChrolut-EN and methanol (99.9\%) were obtained from Merck (Darmstadt, Germany), whereas dichloromethane (99.8\%) and ethyl acetate (99.8\%) from LabScan (Dublin, Ireland). The ProZym M, enzyme was supplied by ProEnol (Porto, Portugal), whereas the almond $\beta$-glucosidase (EC 3.2.1.21) was obtained from Fluka (Buchs, Switzerland). The ProZym M (24U/mg solid) and almond b-glucosidase ( $8 \mathrm{U} / \mathrm{mg}$ solid) possess $\beta$-glucosidase activity, and also exhibit considerable galactosidase activity. The almond bglucosidase (EC 3.2.1.21) is a relatively stable enzyme retaining its catalytic activity over the $\mathrm{pH}$ range 2-9, and temperature of 30 to $50^{\circ} \mathrm{C}$. ProZym $\mathrm{M}$ is active between $\mathrm{pH} 3$ to 6 , and a temperature ranging from 12 to $50^{\circ} \mathrm{C}$. Their optimal activity conditions were $\mathrm{pH} 5$ and temperature of $40^{\circ} \mathrm{C}$. The standards of volatile compounds used to perform the identification of target 


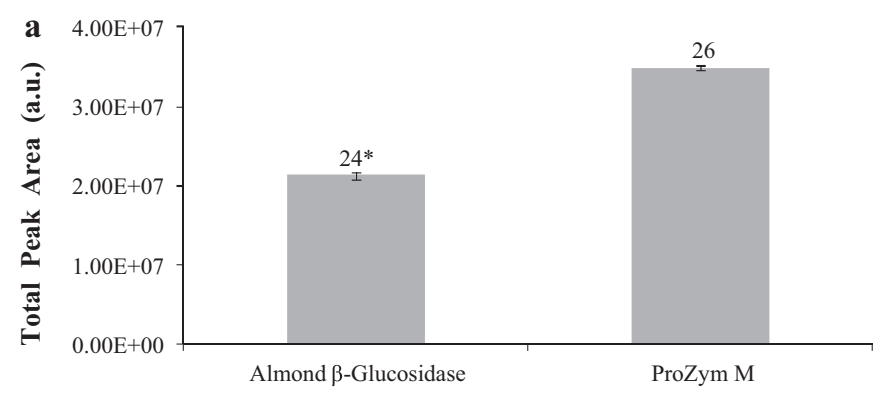

Commercial enzymatic preparation

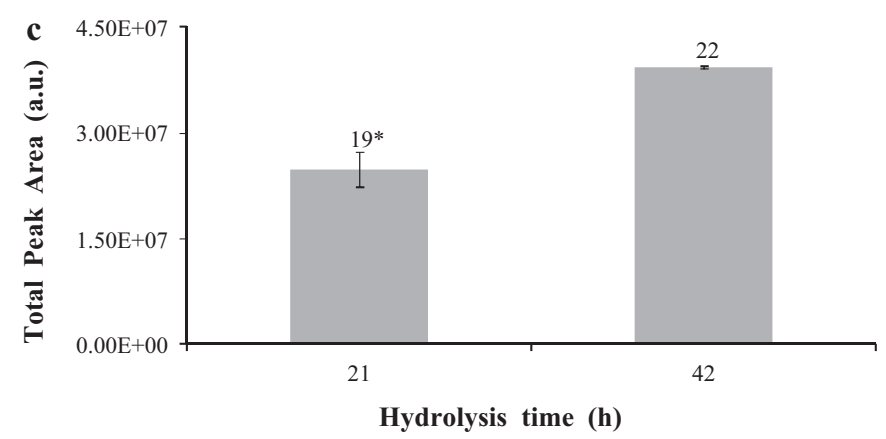

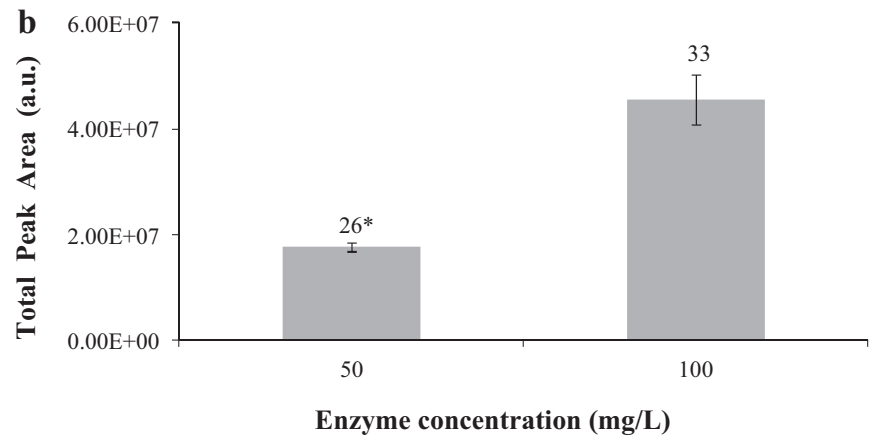

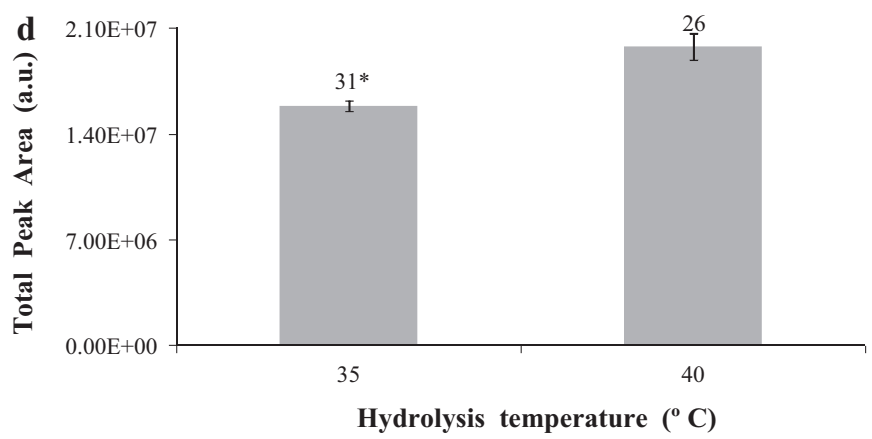

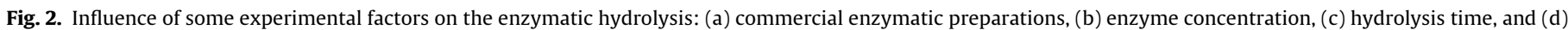
hydrolysis temperature. $\left({ }^{*}\right)$ Number of identified compounds. a.u. - arbitrary unit.

compounds were purchased from Acros Organics (Geel, Belgium), Fluka (Buchs, Switzerland), and Sigma-Aldrich (Madrid, Spain) with purity higher than $98 \%$. The individual stock solutions were prepared in ethanol at concentration of $1000 \mathrm{mg} / \mathrm{L}$ and stored at $4^{\circ} \mathrm{C}$. Ultra-pure water from Milli-Q system (Millipore, Bedford, USA) with conductivity of $18 \mathrm{M} \Omega$ was used throughout. The glass vials, SPME fiber and SPME holder for manual sampling were purchased from Supelco (Bellefonte, PA, USA). The retention index probes (RI) was calculated through injection of an $n$-alkanes series of $\mathrm{C}_{8}-\mathrm{C}_{20}$ straight-chain alkanes (concentration of $40 \mathrm{mg} / \mathrm{L}$ in $n$ hexane) supplied from Fluka (Buchs, Switzerland).

\subsection{Grape samples}

Healthy state V. vinifera L. grapes, Malvasia Cândida, Malvasia Roxa, Bual, Sercial, Terrantez, Verdelho, and Tinta Negra from 2008 harvest were collected, when they reached maturity based on maximum sugar content and minimum titratable acidity, from three experimental vineyards, located in the south of Madeira Island (Portugal). Malvasia Cândida, Malvasia Roxa, Bual, Sercial, Terrantez, and Verdelho were harvested in Estreito da Calheta (Quinta das Vinhas vineyard, $32^{\circ} 44^{\prime} 0.09^{\prime \prime} \mathrm{N}, 17^{\circ} 11^{\prime} 14.80^{\prime \prime} \mathrm{W}$ ), whereas Tinta Negra in Estreito de Câmara de Lobos (Vila Afonso vineyard, $32^{\circ} 39^{\prime} 50.59^{\prime \prime} \mathrm{N}, 16^{\circ} 58^{\prime} 48.28^{\prime \prime} \mathrm{W}$ ) and Jardim da Serra $\left(32^{\circ} 41^{\prime} 42.36^{\prime \prime} \mathrm{N}, 16^{\circ} 59^{\prime} 37.32^{\prime \prime} \mathrm{W}\right)$. These grapes varieties were selected for this research because Malvasia Cândida, Bual, Sercial and Verdelho are noble varieties, and Tinta Negra is the main variety cultivated (around 90\%) in the Madeira Island. Malvasia Roxa and Terrantez grapes are also recommend in the Madeira winemaking. For each variety, ca. $1000 \mathrm{~g}$ of grape berries were picked randomly throughout the vineyard, taking into account the number of berries per bunch, and the balance between shadow and sun exposure. This strategy, following a z-shaped pattern to avoid edge and center effects, contributed to the understanding of the intrinsic and natural variability of the fruit and allowed to validate the data obtained. Samples were transported immediately under refrigeration $\left(\mathrm{ca} .2-5^{\circ} \mathrm{C}\right.$ ) to the laboratory and were stored at $-20^{\circ} \mathrm{C}$ until analysis.

\subsection{Sample preparation}

Prior hydrolyzed components extraction, $200 \mathrm{~g}$ of grape berries (sub-sample from the ca. $1000 \mathrm{~g}$ ) were defrosted at $4{ }^{\circ} \mathrm{C}$ overnight, and then crushed in a turbo blender (Moulinex - LM600E, Ecully, France) during $2 \mathrm{~min}$. The crushed grape suspension was centrifuged at $5000 \mathrm{rpm}$ (Sigma 4K10 Braun, Melsungen, Germany) for $15 \mathrm{~min}$, at room temperature to obtain a clarified crushed grape named as CG sample, which was then filtered through $0.45 \mu \mathrm{m}$ pore size membrane filters (Acrodisc ${ }^{\circledR}$ CR PTFE, Ann Arbor, SOM, USA) and stored at $-20^{\circ} \mathrm{C}$ until analysis. Bual CG sample was selected as the matrix to perform the acid and enzymatic hydrolysis optimization studies.

\subsection{Extraction of glycosidic fraction}

The free and hydrolytically released components present in CG samples were separated using SPE technique developed by Culleré et al. [29], with some modifications. The SPE was performed in an automated VAC ELUT 20 SPE Station manifold 12-port model from Varian (Madrid, Spain). $200 \mathrm{mg}$ of Lichrolut EN were conditioned with $4 \mathrm{~mL}$ dichloromethane (dried under vacuum), followed by $2 \mathrm{~mL}$ of methanol, and finally with $4 \mathrm{~mL}$ of hydroalcoholic solution at $10 \%(\mathrm{v} / \mathrm{v})$. Then, $25 \mathrm{~mL}$ of CG sample were percolated through the sorbent at $5 \mathrm{~mL} / \mathrm{min}$, with the help of vacuum. Subsequently, the column was rinsed with $4 \mathrm{~mL}$ of ultra-pure water to remove sugars, acids and other water-soluble compounds. Thereafter, the free volatiles were eluted with $4 \mathrm{~mL}$ of ethyl acetate at a flow rate of $5 \mathrm{~mL} / \mathrm{min}$, whereas the retained glycosidic fraction was eluted with $2 \mathrm{~mL}$ of methanol. This glycosidic extract was concentrated to dryness under a gentle nitrogen (Air Liquid, Portugal) stream. 
HS-SPME

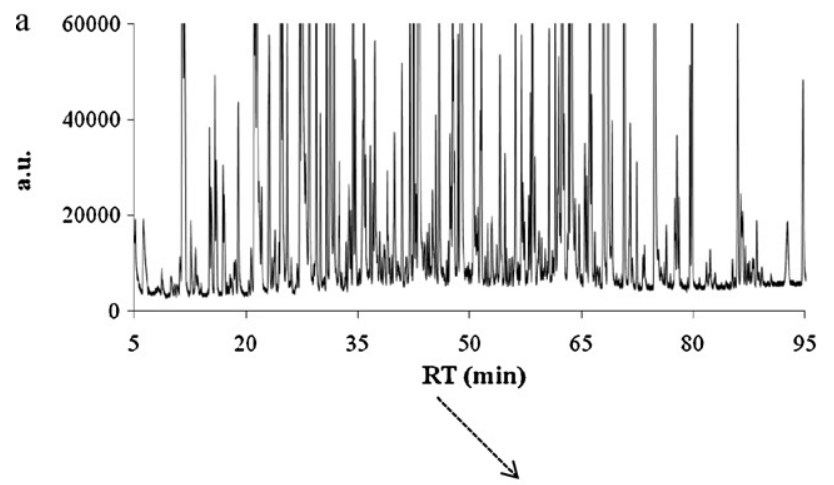

LLE

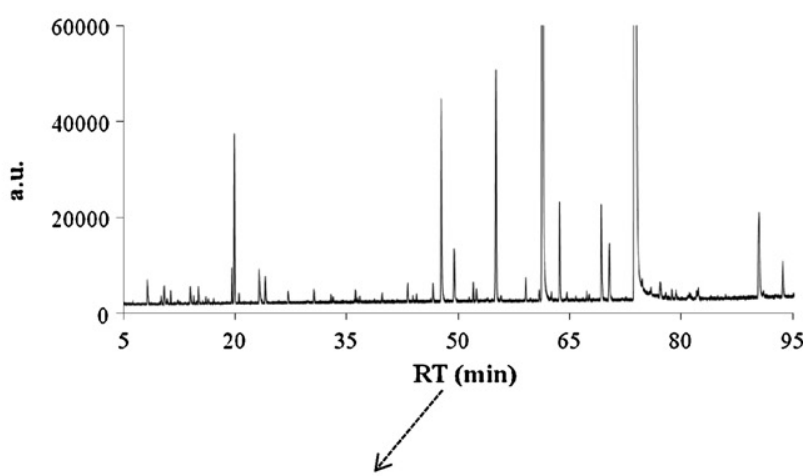

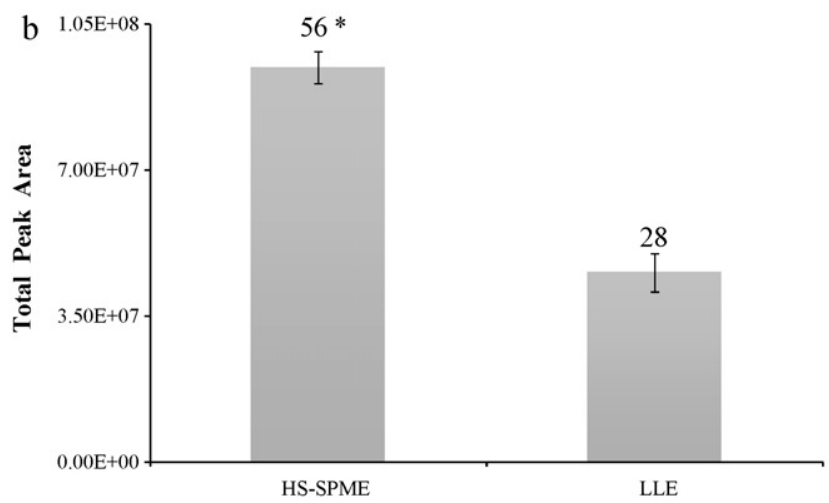

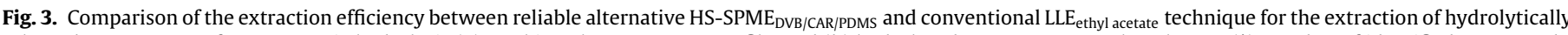

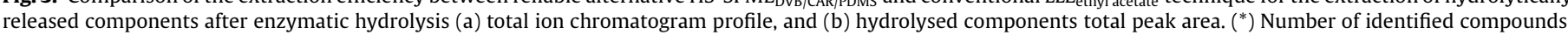
a.u. - arbitrary unit.

\subsection{Hydrolysis of glycosidic extracts}

The dry glycosidic extract was separated in two equal fractions. Each fraction was submitted to a differentiated hydrolysis procedure, acid and enzymatic, to select the most effectiveness procedure to hydrolyze the glycosidically linked components of target $V$. vinifera L. grape juice.

\subsubsection{Enzymatic hydrolysis}

To optimize the enzymatic hydrolysis performance, some experimental parameters were taken into account, namely commercial enzymatic preparations (ProZym M, and almond $\beta$-glucosidase), enzyme concentration ( 50 and $100 \mathrm{mg} / \mathrm{L}$ ), hydrolysis time (21 and $42 \mathrm{~h}$ ) and hydrolysis temperature $\left(35\right.$ and $\left.40^{\circ} \mathrm{C}\right)$. The glycosidic extract was dissolved in $3 \mathrm{~mL}$ of $0.1 \mathrm{M}$ citrate-phosphate buffer $\left(100 \mathrm{~mL}\right.$ of $\mathrm{C}_{6} \mathrm{H}_{8} \mathrm{O}_{7}(20 \mathrm{~g} / \mathrm{L})$ and $100 \mathrm{~mL} \mathrm{Na} \mathrm{HPO}_{4}(71.5 \mathrm{~g} / \mathrm{L})$ in $250 \mathrm{~mL}$ of ultra-pure water, pH 5.0) as described by Oliveira et al. [30], with some modification. After this step, enzymatic treatment with ProZym M $(100 \mathrm{mg} / \mathrm{L}$ dissolved in $0.1 \mathrm{M}$ citrate-phosphate buffer, pH 5.0) was conducted at $35^{\circ} \mathrm{C}$ for $42 \mathrm{~h}$.

\subsubsection{Acid hydrolysis}

To optimize the acid hydrolysis performance, some experimental parameters were taken into account, namely hydrolysis temperature $\left(80\right.$ and $\left.100^{\circ} \mathrm{C}\right)$ and hydrolysis time (30, 60 and $120 \mathrm{~min}$ ). Acid hydrolysis was carried out by reconstituting the dry extract in $3 \mathrm{~mL}$ of citric acid solution ( $0.2 \mathrm{M}, \mathrm{pH} 2.5)$ according to Kotséridis et al. [31]. Then, the vial was capped with a PTFE septum and an aluminum cap, and placed in a thermostated bath adjusted at $100^{\circ} \mathrm{C}$ for $120 \mathrm{~min}$ under a nitrogen atmosphere.

\subsection{Extraction of hydrolytically released components}

Two extraction procedures, HS-SPME $\mathrm{DVB}_{\mathrm{D} / \mathrm{CAR} / \mathrm{PDMS}}$ (alternative technique) and LLE ethyl acetate (conventional technique), were tested and compared, in order to evaluate their effectiveness to extract the hydrolytically released components from Bual CG sample.

For LLE assay, after addition of $0.2 \mathrm{~g}$ of $\mathrm{NaCl}$, the hydrolyzed components $(3 \mathrm{~mL})$ were successive extracted with $1.5 \mathrm{~mL}$ of ethyl acetate. The extract was dried over anhydrous sodium sulfate, and then concentrated to a final volume of $500 \mu \mathrm{L}$ under a stream of nitrogen, and frozen at $-20^{\circ} \mathrm{C}$ until analyzed by GC-qMS.

Regarding the HS-SPME technique, the SPME coating fiber (DVB/CAR/PDMS) and the experimental parameters used were adapted from a previously developed work in our laboratory to analyze the free fraction grape volatiles [32]. For the HS-SPME assay, $3 \mathrm{~mL}$ of hydrolyzed components were placed into a $10 \mathrm{~mL}$ glass vial from Supelco (Bellefonte, PA, USA). After the addition of $0.6 \mathrm{~g}$ of $\mathrm{NaCl}$ and stirring bar $(2 \mathrm{~mm} \times 0.5 \mathrm{~mm})$, which correspond to a ratio of the volume of the liquid phase to the headspace volume $(1 / \beta)$ of 0.5 , the vial was capped with a PTFE septum, and an aluminum cap (Chromacol, Hertfordshire, UK). The vial was placed in a thermostatted bath adjusted to $60.0 \pm 0.1^{\circ} \mathrm{C}$ for $5 \mathrm{~min}$, and then the DVB/CAR/PDMS fiber $(50 / 30 \mu \mathrm{m})$ was inserted in the headspace for $45 \mathrm{~min}$ under constant stirring (400 rpm). Each sample was analyzed, at least, in triplicate. Prior to use, the SPME fiber was conditioned at $270^{\circ} \mathrm{C}$ for $60 \mathrm{~min}$ in the GC injector, according to the manufacturer's recommendations. Before the first daily analysis, and to guarantee the absence of peaks in the run blanks and the good quality of the SPME extraction, the fiber was reconditioned for $10 \mathrm{~min}$ at $270^{\circ} \mathrm{C}$. 

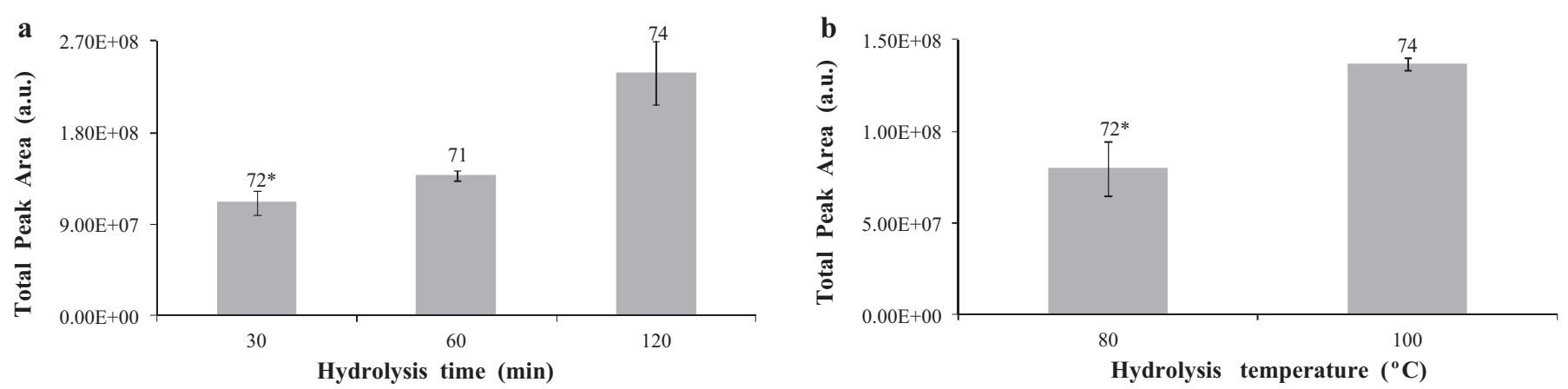

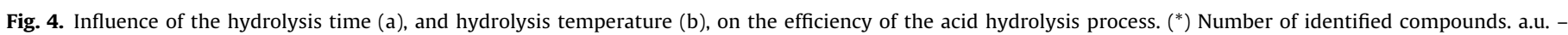
arbitrary unit.

\subsection{GC-qMS conditions}

Agilent Technologies $6890 \mathrm{~N}$ Network gas chromatography equipped with a BP-20 fused silica capillary column ( $30 \mathrm{~m} \times 0.25 \mathrm{~mm}$ I.D. $\times 0.25 \mu \mathrm{m}$ film thicknesses) supplied by SGE (Darmstadt, Germany) interfaced to an Agilent 5973 N quadrupole mass selective detector was used for separation and identification of hydrolyzed components. Helium (Air Liquid, Portugal) was used as the carrier gas at a constant flow rate of $1 \mathrm{~mL} / \mathrm{min}$; injections were performed in the splitless mode (straight glass liner, $0.75 \mathrm{~mm}$ I.D.). The following GC oven temperature program was applied: $40^{\circ} \mathrm{C}$ for $5 \mathrm{~min}$, then ramped at $2{ }^{\circ} \mathrm{C} / \mathrm{min}$ to $220^{\circ} \mathrm{C}$, and held there for $10 \mathrm{~min}$. For the MS system, the temperatures of the transfer line, quadrupole and ionization source were 250, 150 and $230^{\circ} \mathrm{C}$, respectively; electron impact mass spectra were recorded at $70 \mathrm{eV}$ ionization voltages and the ionization current was about $30 \mu \mathrm{A}$. The acquisitions were performed in full scan mode (the mass-to-charge ratio range used was $30-300 \mathrm{~m} / \mathrm{z}$ ). The GC peak area of each hydrolyzed component was obtained from the ion extraction chromatogram (IEC) by selecting target ions for each one. Reproducibility was expressed as relative standard deviation (RSD). Signal acquisition and data processing were performed using the HP ChemStation (Agilent Technologies). Identification of hydrolyzed components was carried out by: (i) comparing the GC retention times and mass spectra, with those, when available, of the pure standard compounds, (ii) all mass spectra were also compared with the data system library (NIST, 2005 software, Mass Spectral Search Program V.2.0d; NIST 2005, Washington, DC), and (iii) retention index probes (RI) value were determined according to the van den Dool and Kratz [33]. For the RI determination, a $\mathrm{C}_{8}-\mathrm{C}_{20} n$-alkanes series were used, and these values were compared, when available, with values reported in the literature for a BP-20 and similar chromatographic columns [34-52].

\subsection{Statistical analysis}

Principal components analysis (PCA) was applied to the auto-scaled areas of the 79 components released by enzymatic hydrolysis of Malvasia Cândida, Malvasia Roxa, Bual, Sercial, Terrantez, Verdelho, and Tinta Negra by HS-SPME/GC-qMS methodology, each with three independent replicates, using the Unscrambler software package. The goal was to extract the main sources of variability and hence to help on the characterization of the dataset [53].

\section{Results and discussion}

The first stage of this study addressed the optimization of parameters that influence the effectiveness of enzymatic and acid hydrolysis toward hydrolytically released components from selected $V$. vinifera L. grape juices. The best conditions were chosen based on intensity response (total GC peak area) obtained by GC analysis, number of identified compounds and relative standard deviation (RSD, \%).

\subsection{Hydrolytically released components by enzymatic hydrolysis}

Some parameters that influence the performance of enzymatic hydrolysis, namely commercial enzymatic preparations (Prozym $\mathrm{M}$, and almond $\beta$-glucosidase), enzyme concentration (50 and $100 \mathrm{mg} / \mathrm{L}$ ), hydrolysis time ( 21 and $42 \mathrm{~h}$ ), and hydrolysis temperature $\left(35\right.$ and $40^{\circ} \mathrm{C}$ ), were evaluated and compared. The effect $\mathrm{pH}$ was not considered, since its influence on the response of aglycone released was negligible when compared to other parameters. Therefore, $\mathrm{a} \mathrm{pH}=5.0$ was used in the enzymatic hydrolysis assays, which is in agreement with the previous studies [3,7,22,23,25,54]. The ability to break the glycosidic bond and release the aglycone, applying the same enzyme concentration $(50 \mathrm{mg} / \mathrm{L})$, was as follow: ProZym $M>$ almond $\beta$-glucosidase (Fig. 2a). The ProZym $M$ and almond b-glucosidase enzymatic preparations tested have $\beta$ glucosidase activity and also exhibit considerable galactosidase activity, nevertheless, it was observed different hydrolysis efficiency probably due to their enzymatic activities, 24 and $8 \mathrm{U} / \mathrm{mg}$ solid, respectively. Previous studies have been applied successfully enzymes with $\beta$-glucosidase activity to release the aglycones from fruit glycosidic extracts, like banana [26] and pineapple [27]. The ability, expressed as GC peak area (i.e. amount of hydrolyzed components), to promote the release of hydrolyzed components was twice higher when the enzyme (ProZym M) concentration was doubling (Fig. 2b). The overall increase of the total GC peak area with the enzyme concentration indicate that the enzyme activity is enhanced with the increase of enzyme content as well, which is in accordance with previous literature findings [55]. Nevertheless, the effect of enzyme concentration (Fig. 2b) and/or incubation time (Fig. 2c) was more pronounced than incubation temperature (Fig. 2d). The increase on GC peak area with the increase of incubation time, from 21 to $42 \mathrm{~h}$, means that using $21 \mathrm{~h}$ as incubation time is not enough to complete the hydrolysis process. Based on the obtained results, the best hydrolysis conditions were achieved using ProZym M ( $\beta$-glucosidase activity) with a concentration of $100 \mathrm{mg} / \mathrm{L}$, an incubation temperature of $35^{\circ} \mathrm{C}$ for $42 \mathrm{~h}$ of incubation time.

\subsubsection{Comparison of the HS-SPME-based alternative approach with the conventional LLE technique to extract the hydrolytically released components by enzymatic hydrolysis}

In the present research, the aglycones released by enzymatic hydrolysis were extracted using $\mathrm{HS}_{-} \mathrm{SPME}_{\mathrm{DVB} / \mathrm{CAR} / \mathrm{PDMS}}$ and LLE $_{\text {ethyl acetate }}$ techniques, in order to evaluate and compare their potentialities to extract the hydrolyzed components from $V$. vinifera 


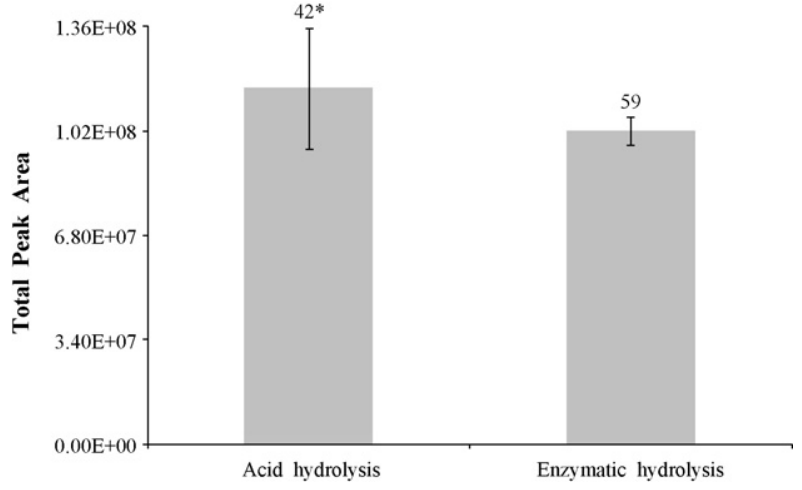

Fig. 5. Comparison of the effectiveness of acid and enzymatic hydrolysis procedure to release the glycosidic components from $V$. vinifera L. grape. *Number of identified compounds.

L. grape juice. As can be seen in Fig. 3, the HS-SPME $E_{D V B / C A R / P D M S}$ showed better extraction efficiency, in terms of GC peak area and number of identified and extracted compounds, than conventional LLE $_{\text {ethyl acetate }}$ technique.

In this sense, more than 50 hydrolytically released components belonging to different chemical groups, like terpenoids (10 HS-PME $E_{D V B / C A R / P D M S}$ and 3 LLE $\left._{\text {ethyl acetate }}\right), \mathrm{C}_{13}$ norisoprenoids (3 $\mathrm{HS}_{\mathrm{PME}} \mathrm{DVB}_{\mathrm{DVAR} / \mathrm{PDMS}}$ and $1 \mathrm{LLE}_{\text {ethyl acetate}}$ ), alcohols (10 HS$\mathrm{PME}_{\mathrm{DVB} / \mathrm{CAR} / \mathrm{PDMS}}$ and $8 \mathrm{LLE}_{\text {ethyl acetate), carbonyl compounds }}$

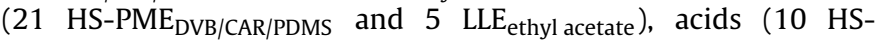
$\mathrm{PME}_{\mathrm{DVB} / \mathrm{CAR} / \mathrm{PDMS}}$ and $\left.10 \mathrm{LLE}_{\text {ethyl acetate }}\right)$, volatile phenols (2

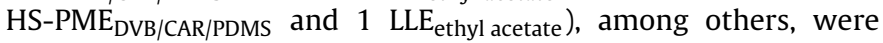
extracted from $V$. vinifera $L$. grape juice. The main advantage of LLE technique is that the extraction is carried out at low temperature, and in an oxygen-free atmosphere, which decrease the possibility of thermal degradation, oxidation and chemical reaction between the extracted components [56]. Nevertheless, this technique requires an organic solvent (ethyl acetate) that is toxic, and has more affinity to extract high polar compounds, like acids (52\%), and volatile phenols (9\%) compared to HS-SPME, 23 and

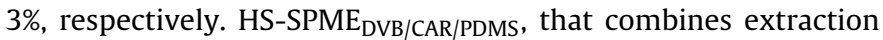
and concentration in unique step, has highest affinity to extract carbonyl compounds (36\%), alcohols (31\%), and terpenoids (7\%) compared to LLE technique, 19, 14 and 5\%, respectively. The highest affinity to extract terpenoids by HS-SPME $E_{D V B / C A R / P D M S}$, can be attributed to a low affinity of these chemical groups to aqueous sample, and consequently their low water/solvent partition coefficients $[57,58]$. According to a previous study, terpenoids (e.g. linalool, $\alpha$-terpeniol, geraniol) have a great sensorial relevance to the wine aroma due to their extremely low odor threshold, which can impart citrus, sweet, and floral odors to the wines [59]. Similar results were observed by Dziadas et al. [24] in the analysis of terpenoids released by acid hydrolysis in white wines using HSSPME/GC-qMS methodology. According to the obtained results the HS-SPME techniques was revealed as an improved and powerful strategy to extract the hydrolytically released components by enzymatic hydrolysis in comparison to the conventional LLE technique, and therefore can be considered as the most appropriate technique to do this aim. In combination with GC-qMS, HS-SPME is an useful tool to establish the pattern of hydrolyzed components from $V$. vinifera L. grape.

\subsection{Hydrolytically released components by acid hydrolysis}

In previous studies the glycosidic extract has been hydrolyzed with citric acid $(\mathrm{pH}=2.5)$ at $100^{\circ} \mathrm{C}$ for $60 \mathrm{~min}$ [6,31]. However, acid hydrolysis at high temperature could result in aglycones degradation. So, to avoid a possible degradation, the acid hydrolysis conditions $(\mathrm{pH}=2.5)$ were evaluated at different times $(30,60$ and $120 \mathrm{~min}$ ) and temperatures $\left(80\right.$ and $\left.100^{\circ} \mathrm{C}\right)$. As observed in Fig. $4 \mathrm{a}$ and $\mathrm{b}$, although the number of identified compounds did not present significant differences ( 71 to 74 ) regarding to the acid hydrolysis time and temperature, it was observed an increase in the GC peak area with the increasing of the hydrolysis time, namely between 60 and $120 \mathrm{~min}$, and hydrolysis temperature. The best performance for acid hydrolysis was obtained at $100^{\circ} \mathrm{C}$ for $120 \mathrm{~min}$.

\subsection{Acid vs enzymatic hydrolysis}

The performance of the acid and enzymatic hydrolysis procedures using the alternative $\mathrm{HS}-\mathrm{SPME}_{\mathrm{DVB} / \mathrm{CAR} / \mathrm{PDMS} / \mathrm{GC}-\mathrm{qMS}}$ approach was illustrated in Fig. 5.

A total of 59 and 42 hydrolytically released components (including terpenoids, $C_{13}$ norisoprenoids, alcohols, carbonyl compounds, acids and volatile phenols) were released from $V$. vinifera $\mathrm{L}$. grape juice by enzymatic and acid hydrolysis, respectively. The predominant chemical groups obtained by enzymatic hydrolysis were carbonyl compounds (36\%), followed by alcohols (35\%), acids (18\%), terpenoids (10\%), $C_{13}$ norisoprenoids $(0.5 \%)$, and volatile phenols $(0.4 \%)$, whereas by acid hydrolysis acids ( $46 \%)$, followed by a group of not identified compounds with specific fragment ions $(\mathrm{m} / \mathrm{z}=157$, $119,159)(17 \%)$, terpenoids (14\%), alcohols (8\%), carbonyl compounds (7\%), $\mathrm{C}_{13}$ norisoprenoids (6\%), and volatile phenols $(0.2 \%)$, were found the major chemical groups. Despite acid hydrolysis release more terpenoids and $C_{13}$ norisoprenoids compared to enzymatic hydrolysis, some of these volatiles (e.g. monoterpene oxide) are presumably artifacts as a result of the sample preparation and temperature applied in the procedure. The enzymatic hydrolysis involves a cleavage of the glycosidic linkage, and therefore does not induce any further transformation into chemical structure of the aglycone released [21]. For this reason the enzymatic hydrolysis of glycosidic extract using an enzyme with $\beta$-glucosidase activity, Prozym M was chosen. The ability of the enzyme with $\beta$ glucosidase activity to release the aglycone from grapes has been previously described $[6,10,22,23]$.

\subsection{Application of the HS-SPME/GC-qMS approach for profiling the pattern of hydrolytically released components from $V$. vinifera L. grape juice}

After optimization studies, the HS-SPME/GC-qMS methodology was applied, as a reliable alternative to the commonly used LLE, for profiling the pattern of hydrolytically released components from $V$. vinifera L. grapes. The GC peak area of released components by enzymatic hydrolysis, using the enzyme with $\beta$-glucosidase activity, and their relative standard deviation (\% RSD) are illustrated in Table 1.

A total of 79 hydrolytically released components were identified in the $V$. vinifera L. grape juice (Table 1 ), which included 17 terpenoids, $6 \mathrm{C}_{13}$ norisoprenoids, 14 alcohols, 16 carbonyl compounds, 10 esters, 11 acids, 4 volatile phenols, and 1 pyrazine. These hydrolytically released components were identified by their mass spectrum, retention index probes (using $C_{8}-C_{20} n$-alkanes), and further confirmed by pure standards, when available. The predominant chemical groups found in the hydrolyzed fraction of studied $V$. vinifera L. grape juices were alcohols (e.g. benzyl alcohol, 2-phenylethyl alcohol, 2-ethylhexanol), and acids (e.g. sorbic acid, benzoic acid), which accounted, on average, 34 and 29\% of the total of hydrolyzed fraction, respectively. Nevertheless, special attention should be also given to terpenoids found in grapes of Malvasia Cândida and Malvasia Roxa varieties, which accounted 23 and 13\% for the total of hydrolyzed fraction, respectively. The total GC peak area of terpenoids in Malvasia Cândida was two times higher than that 
Table 1

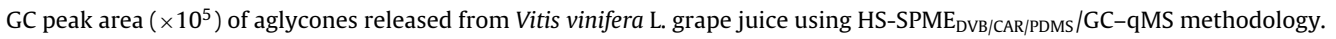

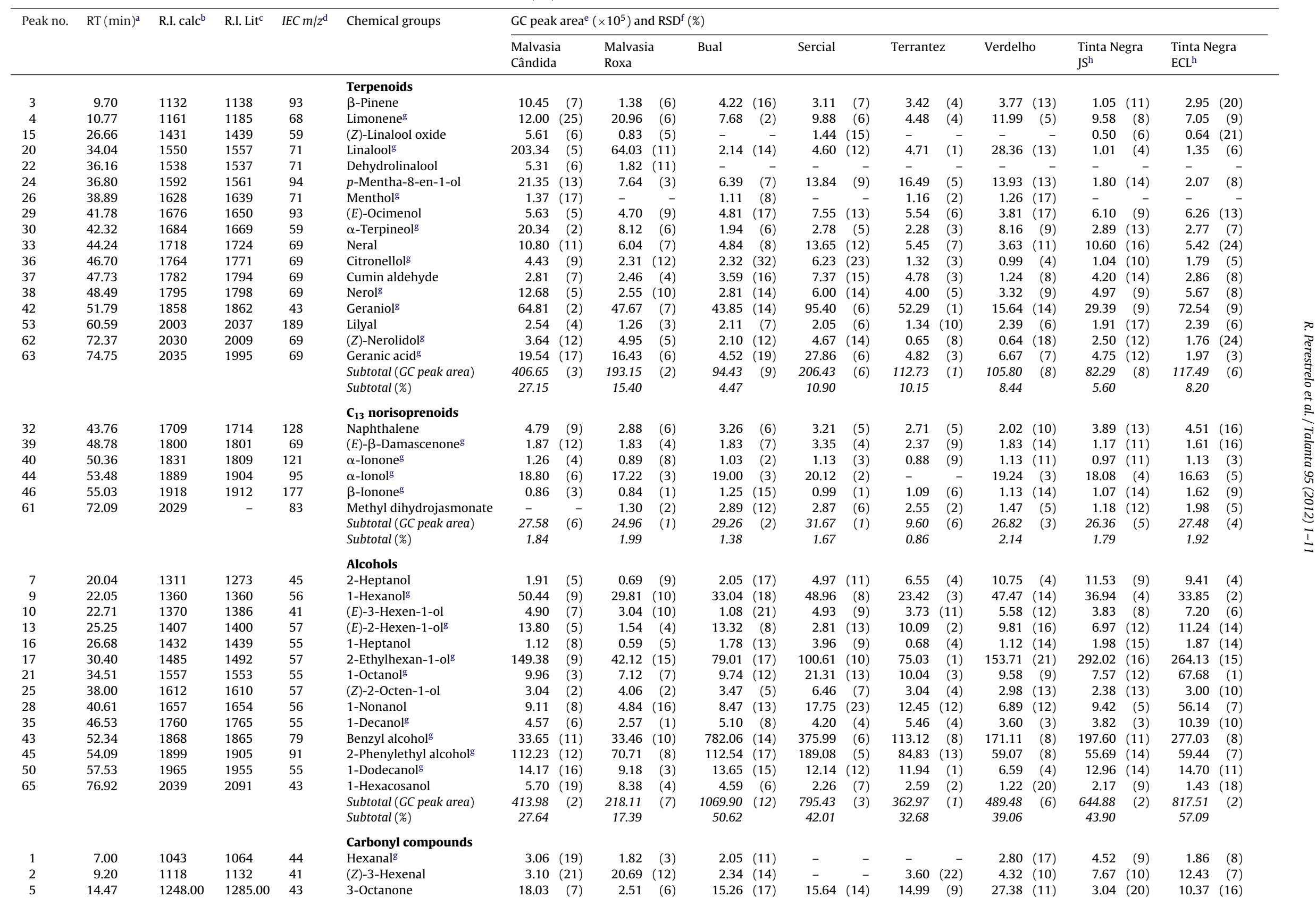




\begin{tabular}{|c|c|c|c|c|c|c|c|c|c|c|c|c|c|c|c|c|}
\hline \multirow[t]{2}{*}{ Peak no. } & \multirow[t]{2}{*}{$\mathrm{RT}(\min )^{\mathrm{a}}$} & \multirow[t]{2}{*}{ R.I. calc ${ }^{\mathrm{b}}$} & \multirow[t]{2}{*}{ R.I. Lit ${ }^{\mathrm{c}}$} & \multirow[t]{2}{*}{$I E C \mathrm{~m} / \mathrm{z}^{\mathrm{d}}$} & \multirow[t]{2}{*}{ Chemical groups } & \multicolumn{11}{|c|}{ GC peak area $\left(\times 10^{5}\right)$ and $\operatorname{RSD}^{f}(\%)$} \\
\hline & & & & & & $\begin{array}{l}\text { Malvasia } \\
\text { Cândida }\end{array}$ & $\begin{array}{l}\text { Malvasia } \\
\text { Roxa }\end{array}$ & \multicolumn{2}{|l|}{ Bual } & \multicolumn{2}{|l|}{ Sercial } & Terrantez & \multicolumn{2}{|c|}{ Verdelho } & $\begin{array}{l}\text { Tinta Negra } \\
\mathrm{JS}^{\mathrm{h}}\end{array}$ & $\begin{array}{l}\text { Tinta Negra } \\
\text { ECL }^{\mathrm{h}}\end{array}$ \\
\hline 6 & 16.77 & 1276 & 1280 & 41 & Octanal & $2.89(12)$ & $2.23(15)$ & - & - & 2.96 & (3) & $1.32(15)$ & 5.58 & (5) & $2.57 \quad(4)$ & $10.89(11)$ \\
\hline 8 & 20.29 & 1332 & 1319 & 43 & 6-Methyl-5-hepten-2-one & $4.56 \quad(8)$ & $5.26 \quad(3)$ & 0.61 & (9) & 3.20 & (19) & $0.50 \quad(1)$ & 1.47 & (9) & $1.87 \quad(5)$ & $4.46(23)$ \\
\hline 12 & 23.42 & 1380 & 1389 & 57 & Nonanal & 15.19 (7) & 7.47 (11) & 2.56 & (17) & 10.75 & (6) & 6.45 & 19.35 & (14) & 11.41 & $25.53(11)$ \\
\hline 14 & 25.71 & 1415 & 1412 & 41 & (E)-2-Octenal & 1.85 & $3.72 \quad(9)$ & 4.70 & (7) & 1.63 & (6) & 1.30 & 1.96 & (14) & $2.01(24)$ & $1.63(20)$ \\
\hline 18 & 31.62 & 1509 & 1515 & 106 & Benzaldehydeg & $13.04(8)$ & $117.42 \quad(5)$ & 23.95 & (6) & 20.87 & (5) & 13.24 & 20.97 & (1) & 178.93 & $19.99 \quad(5)$ \\
\hline 19 & 32.39 & 1523 & 1527 & 43 & (E)-2-Nonenalg & $1.30(14)$ & 1.37 & 0.63 & (7) & 0.92 & (8) & 0.54 & 0.82 & (17) & $1.11 \quad(1)$ & $0.94(18)$ \\
\hline 23 & 36.26 & 1584 & 1543 & 58 & 2-Undecanone & $4.71 \quad(4)$ & 0.99 & 3.92 & (4) & 4.24 & (2) & 3.68 & 2.67 & (13) & $3.39(12)$ & $4.69(12)$ \\
\hline 27 & 39.08 & 1631 & 1633 & 91 & Phenylacetaldehyde ${ }^{g}$ & $9.84(11)$ & 42.46 & 9.62 & (10) & 21.95 & (9) & 6.25 & 8.45 & (17) & $63.92(10)$ & 17.75 \\
\hline 31 & 42.86 & 1693 & 1718 & 57 & Dodecanal & $14.86(10)$ & 12.61 & 11.33 & (8) & 17.86 & (12) & 12.21 & 11.25 & (13) & $15.45(9)$ & $16.26(24)$ \\
\hline 34 & 45.20 & 1736 & 1745 & 70 & $(E)$-2-Dodecenal & $0.93 \quad(4)$ & 0.85 & 0.81 & (8) & 1.03 & (3) & $0.52(13)$ & 1.05 & (9) & 1.00 (7) & $1.05(13)$ \\
\hline 53 & 59.37 & 1999 & 2030 & 95 & 1H-pyrrole-2-carboxaldehyde & $34.73(10)$ & 38.78 & 28.06 & (6) & 38.72 & (6) & $-\quad-$ & 41.87 & (5) & $34.26(13)$ & $22.97 \quad(9)$ \\
\hline 64 & 75.33 & 2036 & - & 129 & 2-(Phenylmethylene)-octanal & 1.19 (6) & 0.96 & 1.22 & (9) & 1.00 & (9) & $0.72(10)$ & 0.61 & (10) & 0.87 & 0.91 \\
\hline \multirow[t]{4}{*}{67} & 79.91 & 2045 & - & 105 & Benzophenone & $4.07(14)$ & 5.19 & 5.31 & (11) & 3.70 & (7) & $4.60 \quad(1)$ & 2.24 & (17) & $3.08(12)$ & 2.88 \\
\hline & & & & & Subtotal (GC peak area) & $133.35 \quad(5)$ & 264.33 & 112.37 & (4) & 144.47 & (4) & 69.92 & 152.79 & (4) & $335.10(11)$ & 154.61 \\
\hline & & & & & Subtotal (\%) & 8.90 & 21.07 & 5.32 & & 7.63 & & 6.29 & 12.19 & & 22.81 & 10.80 \\
\hline & & & & & Acids & & & & & & & & & & & \\
\hline 41 & 50.80 & 1839 & 1847 & 60 & Hexanoic acidg & 10.75 & $6.75 \quad(9)$ & 9.71 & (5) & 7.33 & (7) & 6.43 & 8.85 & (9) & 5.07 & 9.06 \\
\hline 47 & 56.06 & 1938 & 1965 & 73 & 2-Ethylhexenoic acid & 3.87 (4) & $3.75(13)$ & 3.70 & (7) & 3.58 & (3) & $4.14 \quad(9)$ & 3.87 & (9) & $2.72(12)$ & 3.09 \\
\hline 48 & 56.43 & 1945 & 1963 & 60 & Heptanoic acid & $2.96 \quad(8)$ & $1.87 \quad(3)$ & 2.34 & (9) & 2.82 & (2) & 2.65 & 2.95 & (7) & $1.69(14)$ & 2.18 \\
\hline 49 & 57.07 & 1957 & 1962 & 73 & 2-Hexenoic acid & $6.07(10)$ & $1.99 \quad(3)$ & 10.88 & (13) & 2.52 & (8) & 6.38 & 3.15 & (11) & $-\quad-$ & 3.14 (14) \\
\hline 54 & 61.83 & 2007 & 2038 & 60 & Octanoic acid ${ }^{g}$ & $34.75 \quad(9)$ & $28.17 \quad(2)$ & 47.10 & (13) & 31.06 & (5) & $32.16 \quad(6)$ & 38.39 & (10) & 28.83 & $37.34 \quad(5)$ \\
\hline 56 & 65.63 & 2015 & - & 97 & Sorbic acid & 131.16 & $149.46(15)$ & 172.46 & (19) & 197.65 & (6) & 132.17 (11) & 139.44 & (17) & $97.60(15)$ & $56.33(20)$ \\
\hline 58 & 66.93 & 2018 & 2026 & 60 & Nonanoic acid & $15.17 \quad(8)$ & $21.04 \quad(3)$ & 14.37 & (8) & 13.56 & (6) & $17.66 \quad(9)$ & 14.86 & (13) & 10.54 & $14.25 \quad(7)$ \\
\hline 60 & 71.92 & 2029 & 2066 & 60 & Decanoic acidg & $26.22(10)$ & 30.58 & 25.62 & (16) & 19.97 & (9) & 22.26 & 22.93 & (17) & 23.35 (13) & 25.95 \\
\hline 66 & 77.92 & 2041 & - & 105 & Benzoic acidg & $254.90(16)$ & 279.21 & 352.12 & (17) & 391.91 & (3) & 267.28 & 220.82 & (3) & $159.78(20)$ & $84.76(10)$ \\
\hline \multirow[t]{4}{*}{68} & 80.91 & 2047 & - & 60 & Dodecanoic acidg & $6.13(12)$ & 10.19 & 7.22 & (8) & 5.49 & (5) & 5.49 & 3.05 & (9) & $6.31(18)$ & $4.01 \quad(6)$ \\
\hline & & & & & Subtotal (GC peak area) & $491.98 \quad(13)$ & 533.01 & 645.52 & (15) & 675.89 & (3) & 496.62 & 458.31 & (7) & $335.89(14)$ & 240.11 \\
\hline & & & & & Subtotal $(\%)$ & 32.85 & 42.49 & 30.54 & & 35.70 & & 44.71 & 36.57 & & 22.87 & 16.77 \\
\hline & & & & & Volatile phenol & & & & & & & & & & & \\
\hline 51 & 59.09 & 1994 & 1996 & 94 & Phenolg $^{\mathrm{a}}$ & $4.48 \quad(8)$ & $2.50 \quad(3)$ & 2.90 & (4) & 4.60 & (5) & $3.65 \quad(6)$ & 4.08 & (2) & $4.32 \quad(8)$ & 5.19 \\
\hline 55 & 62.98 & 2009 & 2000 & 107 & 2-Methylphenol & $1.64(12)$ & $1.48 \quad(7)$ & 3.12 & (14) & 3.31 & (8) & 2.10 & - & - & $1.74(15)$ & 2.76 \\
\hline 57 & 66.60 & 2020 & 2071 & 164 & Eugenolg $^{\mathrm{g}}$ & $4.27(12)$ & $4.80 \quad(5)$ & 141.40 & (16) & 13.30 & (5) & 39.80 (3) & 5.71 & (5) & $30.82(13)$ & 56.39 \\
\hline \multirow[t]{4}{*}{59} & 67.93 & 2020 & 2054 & 135 & 2-Methoxy-4-vinylphenol & $11.38(14)$ & $10.94 \quad(2)$ & 13.20 & (10) & 15.30 & (2) & 11.33 & 6.81 & (12) & $5.87(13)$ & 8.81 \\
\hline & & & & & Subtotal (GC peak area) & $21.77 \quad(8)$ & 19.72 & 160.62 & (15) & 36.51 & (4) & $56.88 \quad(1)$ & 16.60 & (7) & 42.75 & 73.15 \\
\hline & & & & & Subtotal (\%) & 1.45 & 1.57 & 7.60 & & 1.93 & & 5.12 & 1.32 & & 2.91 & 5.11 \\
\hline & & & & & Pyrazines & & & & & & & & & & & \\
\hline \multirow[t]{3}{*}{11} & 23.08 & 1375 & 1411 & 121 & 2-Ethyl-6-methylpyrazine & $2.56(19)$ & $1.29(11)$ & 1.34 & (17) & 2.95 & (20) & 2.10 & 3.40 & (2) & $1.62(17)$ & $1.74(14)$ \\
\hline & & & & & Subtotal (GC peak area) & $2.56(19)$ & $1.29(11)$ & 1.34 & (17) & 2.95 & (20) & 2.10 & 3.40 & (2) & $1.62(17)$ & $1.74(14)$ \\
\hline & & & & & Subtotal (\%) & 0.17 & 0.10 & 0.06 & & 0.16 & & 0.19 & 0.27 & & 0.11 & 0.12 \\
\hline
\end{tabular}

$-:$ not detected.

a Retention times (RT).

b RI: retention index calculated for a BP-20 column.

c RI: retention index reported in the literature for BP-20 columns or equivalents [34-52].

d IEC: ion extraction chromatogram, $m / z$ used to obtained the GC peak area of each compound.

e Mean of three replicates.

f RSD: relative standard deviation.

$\mathrm{g}$ Identification confirmed by comparing mass spectra and retention time with those standards.

h Tinta Negra JS: Tinta Negra variety from Jardim da Serra (South of Island); Tinta Negra ECL: Tinta Negra variety from Estreito de Câmara de Lobos (South of Island). 

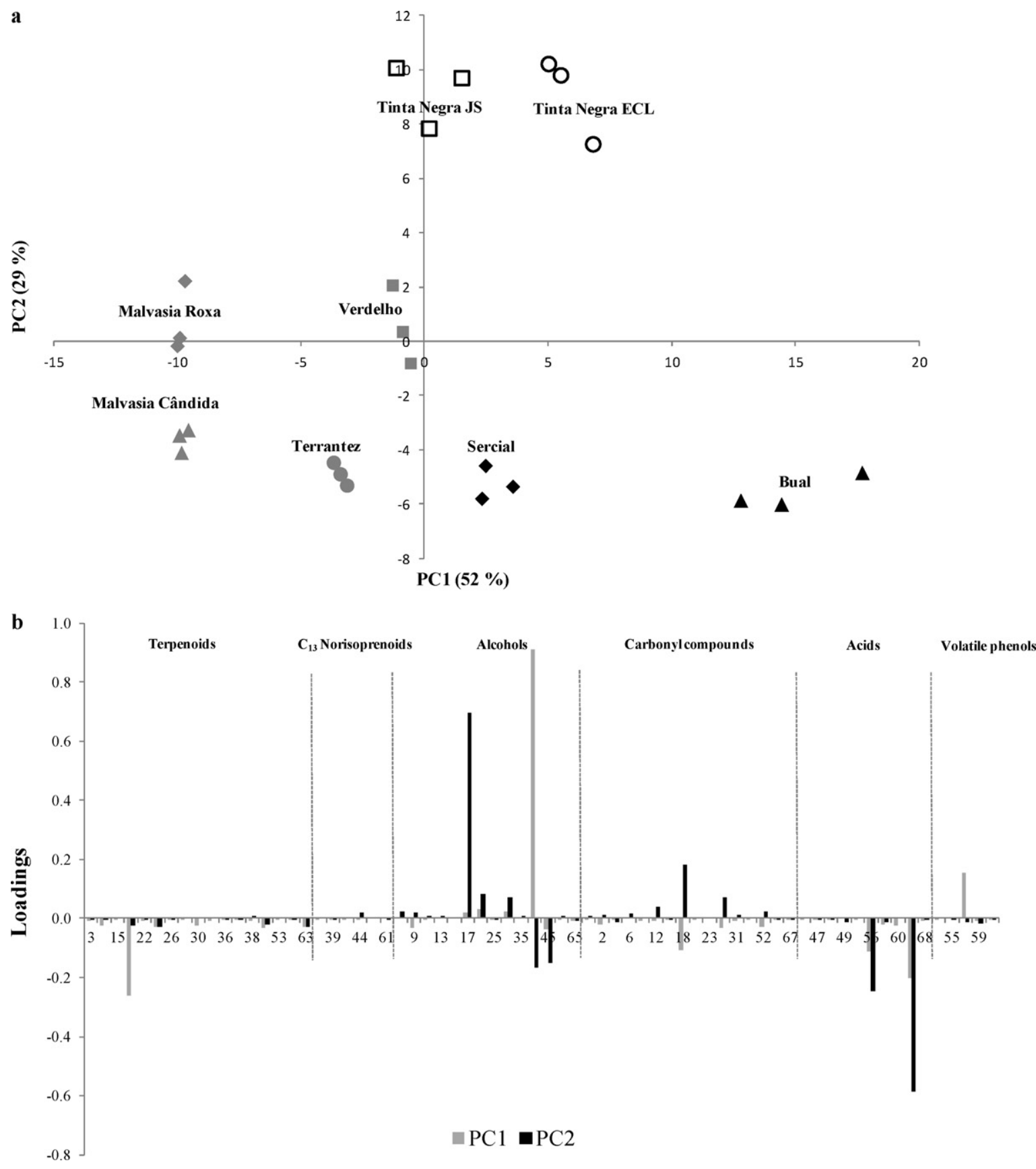

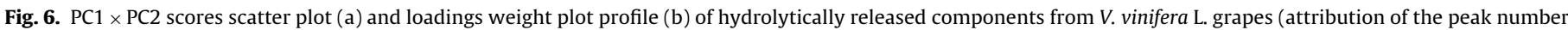
is shown in Table 1 ).

found in Malvasia Roxa and Sercial grapes and four times higher than in the remaining $V$. vinifera L. grapes under study (Table 1), although the number of identified compounds was quite similar. For all $V$. vinifera L. grapes considered in this research, the predominant terpenoids were linalool and geraniol, accounting for 37 (Tinta Negra, JS) and 66\% (Malvasia Cândida) of the terpenoids total GC peak area. According to results obtained by PCA (Fig. 6), the Malvasia Cândida and Malvasia Roxa (PC1 and PC2 negative) was mainly characterized by linalool and geraniol, and its presence based on previous studies could contribute positively to wine aroma with citrus, sweet and flowery odors. (Z)-Nerolidol is the only sesquiterpenoid identified in the investigated $V$. vinifera $L$. grape juice, and its GC peak area is highest for Malvasia Cândida, Malvasia Roxa, and Sercial grape varieties. Concerning to $C_{13}$ norisoprenoids the total GC peak area are similar, with exception of Terrantez grapes where the $\mathrm{C}_{13}$ norisoprenoid content is almost two times lower than the other $V$. vinifera $L$. grapes. Among them, $\alpha$-ionol is the predominant $\mathrm{C}_{13}$ norisoprenoid in all varieties, except for Terrantez, where this compound was not detected.

Regarding to alcohols, the GC peak area is highest for Bual, Sercial and Tinta Negra (from two different localizations) grapes. For all $V$. vinifera L. investigated grapes the predominant alcohols identified in the hydrolyzed fraction were benzyl alcohol, phenylethyl alcohol, and 2-ethylhexanol. Their contributions to the total hydrolyzed fraction are different for the grape varieties under study, ranging from 10 (Malvasia Roxa) to 40 (Bual) \%. According to the obtained PCA results (Fig. 6), Tinta Negra (PC1 and PC2 positive) was mainly characterized by 2-ethylhexan-1-ol, whereas Bual and Sercial projected in PC1 positive and PC2 negative are characterized by benzyl alcohol and 2-phenylethyl alcohol. The presence 
of these two aromatic alcohols is associated to sweet and flowery notes and its contribution can be considered as a positive characteristic specially, for grape varieties with a poor varietal character. The total carbonyl compounds GC peak area in Tinta Negra (from Jardim da Serra) and Malvasia Roxa is two times higher than the other $V$. vinifera L. grapes under study, due mainly to the contribution of benzaldehyde, representing 53 and $44 \%$ of the total carbonyl compounds GC peak area, respectively. Verdelho grapes located in PC1 negative and PC2 positive are mainly characterized by benzaldehyde, whose aroma descriptor is referred to bitter almonds. Concerning to the acids, the lowest total GC peak area was found in Tinta Negra grapes (from Estreito de Câmara de Lobos), two times higher compared to the remaining $V$. Vinifera $L$. grapes investigated. Among them, sorbic acid and benzoic acid are predominant in all studied grape varieties. Terrantez grapes located in PC1 and PC2 negative (Fig. 6) are mainly characterized by benzoic acid. Regarding to esters the total GC peak are similar for all investigated grapes with exception of Verdelho grapes, where the esters content is almost two times lower than the other $V$. vinifera L. grapes. Methyl 2-hydroxybenzoate and ethyl hexadecanoate, are the predominant esters in all grapes of different varieties, except for Verdelho grapes.

According previous studies connected to the sensorial properties of food related matrices and the results obtained by PCA, it was expected that the Madeira wine sensorial properties, particularly for Malvasia Cândida, Malvasia Roxa, Bual, and Sercial grape varieties, could be enriched with enzymatic hydrolysis using an enzyme with $\beta$-glucosidase activity. The hydrolyzed fraction of Malvasia Cândida and Malvasia Roxa grapes is mainly characterized by terpenoids (e.g. linalool, geraniol), while Bual and Sercial grapes are characterized by aromatic alcohols (e.g. benzyl alcohol, 2-phenylethyl alcohol). Terpenoids and aromatic alcohols, when present at concentration above their odor threshold, could contribute positively to wine aroma with citrus, sweet and floral odors.

\section{Conclusions}

In this research, HS-SPME/GC-qMS approach was used as a reliable and attractive technique to establish the pattern of hydrolytically released components from $V$. vinifera $L$. grape juice, commonly used to produce world-famous Madeira wine. At a first step, the enzymatic and acid hydrolysis procedures were optimized. The best results, based on the total GC peak area and number of identified compounds, illustrated that enzymatic hydrolysis using the ProZyme $M$ with $\beta$-glucosidase activity, is the most suitable. Afterwards two extraction procedures, $\mathrm{HS}-\mathrm{SPME}_{\mathrm{DVB} / \mathrm{CAR} / \mathrm{PDMS}}$ (alternative approach) and LLE $_{\text {ethyl acetate (conventional) were }}$ tested and compared in order to evaluate their extraction effectiveness to hydrolytically released components. The best results were achieved using the HS-SPME $E_{D V B / C A R / P D M S}$ technique, which displayed two fold more extraction capacity than the conventional LLE $_{\text {ethyl acetate }}$ technique. A total of 79 hydrolytically released components were detected in the hydrolyzed fraction of the target $V$. vinifera $\mathrm{L}$. grapes using the $\mathrm{HS}-\mathrm{SPME}_{\mathrm{DVB} / \mathrm{CAR} / \mathrm{PDMS} / \mathrm{GC}-\mathrm{qMS}}$ methodology. The major compounds were linalool, geraniol, benzyl alcohol, 2-phenylethyl alcohol, 2-ethylhexan-1-ol, methyl 2-hydroxybenzoate, ethyl hexadecanoate, sorbic acid and benzoic acid. Linalool, geraniol, benzyl alcohol, and 2-phenylethyl alcohol were reported in previous studies as aroma active components of wine, which contributed with citrus, floral, sweet, roses, minty, and fruit notes. The PCA data indicates that the Madeira wine sensorial properties produced from Malvasia Cândida, Malvasia Roxa, Bual and Sercial grapes may be improved by the aglycones released after enzymatic hydrolysis. Malvasia Cândida and Malvasia Roxa were mainly characterized by terpenoids (e.g. linalool, geraniol), while Bual and Sercial by aromatic alcohols (e.g. benzyl alcohol, 2-phenylethyl alcohol). This knowledge represents a suitable tool to support, in an objective way, the winemaker decision based on the varieties potentialities.

The HS-SPME/GC-qMS approach here presented is suitable and very useful for an unambiguous evaluation of hydrolytically released components from $V$. vinifera $L$. grapes. In addition this reliable alternative to conventional LLE technique could be extended to other type of samples namely fruits, vegetables and processed foods.

\section{Acknowledgments}

Rosa Perestrelo was supported by a Ph.D. grant from Fundação para a Ciência e Tecnologia (SFRH/BD/38855/2007). The mass spectrometer used in this work is part of the Portuguese National Mass Spectrometry Network (REDE/1508/RNEM/2005). The authors are also grateful to Instituto do Vinho, do Bordado e do Artesanato da Madeira (IVBAM) for providing the samples used in this study.

\section{References}

[1] R. Baumes, C. Bayonove, R. Cordonnier, P. Torres, A. Seguin, Rev. Fr. Oenol. 116 (1989) 5-11.

[2] S. Bitteur, C. Tesniere, J. Sarris, R. Baumes, C. Bayonove, C. Flanzy, Am. J. Enol. Vitic. 43 (1992) 41-48.

[3] J.J. Mateo, M. Jiménez, J. Chromatogr. A 881 (2000) 557-567.

[4] W. Schwab, P. Schreier, Phytochemistry 29 (1990) 161-164.

[5] M.A. Pedroza, A. Zalacain, J.F. Lara, M.R. Salinas, Food Res. Int. 43 (2010) 1003-1008.

[6] R. Schneider, A. Razungles, C. Augier, R. Baumes, J. Chromatogr. A 936 (2001) $145-157$.

[7] J. Wirth, W.F. Guo, R. Baumes, Z. Günata, J. Agric. Food Chem. 49 (2001) 2917-2923.

[8] M. Fernández-González, R. Di Stefano, A. Briones, Food Microbiol. 20 (2003) 35-41.

[9] C.L. Bayonove, Y.Z. Gütana, J.C. Sapis, R.L. Baumes, Rev. Fr. Oenol. 64 (1992) $15-18$.

[10] S.C. Diéguez, L.C. Lois, E.F. Gómez, M.L.G. de la Peña, LWT - Food Sci. Technol 36 (2003) 585-590.

[11] E. López-Tamames, N. Carro-Mariño, Y.Z. Gunata, C. Sapis, R. Baumes, C. Bayonove, J. Agric. Food Chem. 45 (1997) 1729-1735.

[12] M. Milos, A. Radonic, Food Chem. 68 (2000) 333-338.

[13] E. Sánchez-Palomo, M.C.D.M. Hidalgo, M.Á. González-Viñas, M.S. Pérez-Coello, Food Chem. 92 (2005) 627-635.

[14] D. Chassagne, S. Vernizeau, M. Nedjma, H. Alexandre, Enzyme Microb. Technol 37 (2005) 212-217.

[15] S. Maicas, J.J. Mateo, Appl. Microbiol. Biotechnol. 67 (2005) 322-335.

[16] Y.Z. Günata, C.L. Bayonove, R.L. Baumes, R.E. Cordonnier, J. Sci. Food Agric. 36 (1985) 857-862.

[17] A. Nasi, P. Ferranti, S. Amato, L. Chianese, Food Chem. 110 (2008) 762-768.

[18] E. Sánchez-Palomo, M.E. Alañón, M.C. Díaz-Maroto, M.A. González-Viñas, M.S Pérez-Coello, Talanta 79 (2009) 871-876.

[19] S. Bureau, A. Razungles, R. Baumes, C. Bayonove, J. Food Sci. 61 (1996) 557-560.

[20] P.J. Williams, C.R. Strauss, B. Wilson, R.A. Massy-Westropp, J. Chromatogr. A 235 (1982) 471-480.

[21] M. Ugliano, L. Moio, Anal. Chim. Acta 621 (2008) 79-85.

[22] E. Sánchez-Palomo, M.S. Pérez-Coello, M.C. Díaz-Maroto, M.A. González Viñas, M.D. Cabezudo, Food Chem. 95 (2006) 279-289.

[23] M. Vilanova, C. Sieiro, J. Food Compos. Anal. 19 (2006) 694-697.

[24] M. Dziadas, H.H. Jelen, Anal. Chim. Acta 677 (2010) 43-49.

[25] G. Fan, Y. Qiao, X. Yao, D. Mo, K. Wang, S. Pan, Eur. Food Res. Technol. 229(2009) 571-578.

[26] A.G. Pérez, A. Cert, J.J. Ríos, J.M. Olías, J. Agric. Food Chem. 45 (1997) 4393-4397.

[27] P.Wu, M.C. Kuo, T.G. Hartman, R.T. Rosen, C.T. Ho, J. Agric. Food Chem. 39(1991) $170-172$.

[28] F.M. Musteata, J. Pawliszyn, TrAC - Trends Anal. Chem. 26 (2007) 36-45.

[29] L. Culleré, M. Aznar, J. Cacho, V. Ferreira, J. Chromatogr. A 1017 (2003) 17-26.

[30] J.M. Oliveira, I.M. Araújo, Ó.M. Pereira, J.S. Maia, A.J. Amaral, M. Odete Maia, Anal. Chim. Acta 513 (2004) 269-275.

[31] Y. Kotséridis, R.L. Baumes, G.K. Skouroumounis, J. Chromatogr. A 849 (1999) 245-254.

[32] R. Perestrelo, A.S. Barros, S.M. Rocha, J.S. Câmara, Talanta 85 (2011) 1483-1493

[33] H. van Den Dool, P. Dec Kratz, J. Chromatogr. A 11 (1963) 463-471.

[34] F. Bianchi, M. Careri, A. Mangia, M. Musci, J. Sep. Sci. 30 (2007) 563-572.

[35] T.J. Bruce, A. Cork, J. Chem. Ecol. 27 (2001) 1119-1131.

[36] N.P. Brunton, D.A. Cronin, F.J. Monahan, Flavour Fragr. J. 17 (2002) 327-334

[37] R.G. Buttery, L.C. Ling, D.J. Stern, J. Agric. Food Chem. 45 (1997) 837-843.

[38] H.S. Choi, J. Agric. Food Chem. 51 (2003) 2687-2692.

[39] L. Culleré, A. Escudero, J. Cacho, V. Ferreira, J. Agric. Food Chem. 52 (2004) $1653-1660$. 
[40] N.W. Davies, J. Chromatogr. A 503 (1990) 1-24.

[41] K.H. Engel, R. Tressl, J. Agric. Food Chem. 31 (1983) 998-1002.

[42] V. Ferreira, M. Aznar, R. López, J. Cacho, J. Agric. Food Chem. 49 (2001) 4818-4824.

[43] Á. Högnadóttir, R.L. Rouseff, J. Chromatogr. A 998 (2003) 201-211.

[44] C.H. Hwan, C.C. Chou, J. Sci. Food Agric. 79 (1999) 243-248.

[45] R.N. Kulkarni, G.R. Mallavarapu, K. Baskaran, S. Ramesh, S. Kumar, Flavour Frag. J. 13 (1998) 389-392.

[46] S.J. Lee, A.C. Noble, J. Agric. Food Chem. 51 (2003) 8036-8044.

[47] O. Nishimura, J. Agric. Food Chem. 43 (1995) 2941-2945.

[48] P.K.C. Ong, T.E. Acree, J. Agric. Food Chem. 47 (1999) 665-670.

[49] J. Ruther, J. Chromatogr. A 890 (2000) 313-319.

[50] C. Sanz, D. Ansorena, J. Bello, C. Cid, J. Agric. Food Chem. 49 (2001) 1364-1369.

[51] M. Pontes, J.C. Marques, J.S. Câmara, Talanta 74 (2007) 91-103.
[52] T.Y. Chung, J.P. Eiserich, T. Shibamoto, J. Agric. Food Chem. 41 (1993) 1693-1697.

[53] I.T. Jolliffe, Principal Component Analysis, 2nd ed., Springer, New York, 2002.

[54] J.J. Mateo, N. Gentilini, T. Huerta, M. Jiménez, R. Di Stefano, J. Chromatogr. A 778 (1997) 219-224.

[55] J.I. Taylor, P.B. Grace, S.A. Bingham, Anal. Biochem. 341 (2005) 220-229.

[56] M. Ortega-Heras, M.L. González-SanJosé, S. Beltrán, Anal. Chim. Acta 458 (2002) 85-93.

[57] E. Coelho, R. Perestrelo, N.R. Neng, J.S. Câmara, M.A. Coimbra, J.M.F. Nogueira, S.M. Rocha, Anal. Chim. Acta 624 (2008) 79-89.

[58] M.H. Abraham, R. Kumarsingh, J. Enrique Cometto-Muniz, W.S. Cain, M. Roses, E. Bosch, M. Luisa Diaz, J. Chem. Soc., Perkin Trans. 2 (1998) 2405-2412.

[59] E. Coelho, S.M. Rocha, A.S. Barros, I. Delgadillo, M.A. Coimbra, Anal. Chim. Acta 597 (2007) 257-264 